\title{
Soybean (Glycine Max L.)Growth Enhancement under Water Stress Conditions
}

\author{
Ayman EL Sabagh $^{1 *}$, Sobhy Sorour ${ }^{1}$, Abd Elhamid Omar $^{1}$, Mohammad Sohidul Islam ${ }^{2}$, Akihiro Ueda ${ }^{3}$, \\ Hirofumi Saneoka ${ }^{3}$ and Celaleddin Barutçular ${ }^{4}$ \\ ${ }^{1}$ Department of Agronomy, Faculty of Agriculture, Kafrelsheikh University, Egypt \\ 2Department of Agronomy, Faculty of Agriculture, Hajee Mohammad Danesh Science University, Bangladesh \\ ${ }^{3}$ Plant nutritional physiology, Graduate School of Biosphere Science, Hiroshima University, Japan \\ ${ }^{4}$ Department of Field Crops, Faculty of Agriculture, Cukurova University, Turkey
}

\begin{abstract}
Water stress due to its severity badly effects productivity in legumes. Despite its global importance soybean production suffer the problems of water stress causing damages at plant development. So, the current study aimed at assessing the alleviation of adverse effects of water stress on soybean by using exogenous osmoprotectants and compost application. A greenhouse experiment was conducted at plant nutritional physiology laboratory, Hiroshima University, Japan in 2011- 2012.The treatments as follows, (a) water stress at different soil moisture levels consisting of ( $100 \%$ as control, $75 \%$ and $50 \%$ ), (b) compost fertilizer ( Control, 24 t/ha) and (c) exogenous proline and glycine betaine at the concentrations of (Control and 25Mm) for each. The results indicated that, water stress significantly reduced the seed yield and quality traits. Special attention was paid to the tolerance against water stress was observed, the improvement of water tolerance resulted from proline, glycine betaine and compost were accompanied with improved number of branches, number of pods, 100 seed weight and seed yield per plant. As well as, reduce adverse effects of drought on protein and oil content. These results clearly demonstrate that could be used to reduce the harmful effect of water stress on seed yield and quality aspects of soybean and reduce the amount of water used for irrigation.
\end{abstract}

Keywords: compost, glycine betaine, proline, quality, water stress tolerance, yield

\section{Introduction}

Soybean is particularly sensitive to the lack of moisture during the blooming process and during the legume and seed growing processes [1]. Water stress as a key abiotic limiting factor for soybean production can cause soybean yield reduction up to $40 \%$ or even more [2]. Plant growth and development as well as crop production are highly influenced and sometimes limited by environmental conditions, such as drought, salinity and temperature stresses. Among these, drought stress is the most important environmental constrains to world agricultural production [3].

In response to water deficit/drought conditions, maintenance of cellular osmotic pressure/osmoregulation is the major mechanism [4]. Earlier studies have reported that molecules like glycine betaine and proline act as osmoprotectants under water stress and help to maintain plant growth and development [5]. Organic matter incorporation in the soil has also a positive effect on growth, productivity and yield [6]. Application compost derived from agricultural wastes can improve crop tolerance and increase plant growth via providing better soil structure, supply of nutrients and building up antagonistic microorganisms [7]. Thus, the current study aimed at assessing the alleviation of adverse effects of water deficit stress on soybean by using exogenous osmoprotectants and compost application for increasing the soybean resistance to drought.

\section{Materials and Methods}

\subsection{Plant Material and Water Stress Treatments}

Experiments were conducted in the greenhouse at the Graduate School of Biosphere Science, Hiroshima University, Japan during 2011-2012. The soybean cultivar is Giza 111. The seeds were sown into basin from wood (length 10 meter, width $50 \mathrm{~cm}$, height $50 \mathrm{~cm}$ and depth $350 \mathrm{~cm}$ ) containing a soil mixture of granite regosol soil and perlite $(2: 1 \mathrm{v} / \mathrm{v})$. The experiment was designed as a completely randomized block with arranged a spilt- 
split plot arrangement with four replications. Each plot was fertilized at a rate of $40 \mathrm{~kg} \mathrm{~N} \mathrm{ha}{ }^{-1}, 12 \mathrm{~kg} \mathrm{P}_{2} \mathrm{O}_{5} \mathrm{ha}^{-1}$ and $10 \mathrm{~kg} \mathrm{~K}_{2} \mathrm{O}_{5} \mathrm{ha}^{-1}$ using fertilizer mixture and calcium carbonate $\left(300 \mathrm{~kg} \mathrm{ha}^{-1}\right)$. The treatments could be summarized as follows main plots included (a) water stress at different soil moisture levels consisting of $100 \%$, $75 \%$, and $50 \%$ of field water holding capacity (FC), sub plots included (b) compost application (control, compost (24 ton $\left.\mathrm{ha}^{-1}\right)$, compost was manufactured using wood poop, chicken poop and palm, chemical analysis of compost was: (N: $9.1 \%$, phosphorous: $9.0 \%$, potassium: $5.0 \%$ and $\mathrm{C} / \mathrm{N}: 24)$ and sub-sub plots included (c) exogenous proline and glycine betaine at the concentrations of (control, 25Mm) for each, were applied in different growth stages (V1 and R1). Where, (V1) one fully developed trifoliolate leaf node, (R1) beginning bloom (flowering).

\subsection{Plant Sampling and Measurements}

Seed yield and yield components; at maturity a random sample of ten plants per replication were taken in order to determine: number of branches per plant, number of pods per plan, 100 seed weight and seed yield per plant.

Seed protein (\%); Total nitrogen determined by Kjeldahl method according to AOAC [8]. The crude protein was calculated by multiplying nitrogen percentage by converting factor (6.25) [9].

Oil content; Oil content of seed was estimated according to AOCS [8] using soxhelt apparatus and petroleum ether $\left(40-60^{\circ} \mathrm{C}\right)$ as a solvent.

Statistical analysis; all data collected for both seasons were subjected to analysis of variance according to Gomez and Gomez [10] and treatment means were compared using Duncun Multiple Range Test [11]. All statistical analysis performed using analysis of variance technique by "MSTAT-C" computer software package 1990.

\section{Result and Discussion}

\subsection{Seed Yield and Yield Components}

The current results had highly significant differences were observed among water deficit treatments with respect to seed yield and yield components (Table 1). Imposition of water deficit caused greater reduction seed yield and yield components of stressed plants in respect of normally irrigated ones (Table 1). Actually, the drought stress initiates a series of biochemical and physiological processes in plants which results in the reduction of crop yield [12]. Which can be due to the reduction of fertile pod numbers per plant, seeds number per pod, and seeds weight. This conclusion is consistent with [13]. On the other side, exogenous proline increased significantly seed yield per plant under water stress (Table 1 and Fig. 1.A) In comparison with control, the treatments of proline application increased yield components of soybean under water stress, significantly (Table 1).Many reports demonstrating positive effects of exogenous application of proline on plant growth and final crop yield under drought stress [14].Proline as osmoprotectants promotes plant growth and yield under normal or stress conditions due to its osmoprotective effect on photosynthetic machinery and regulation of ion homeostasis [15]. It could be concluded that proline generally could be used to minimize the harmful effect of water stress on soybean plant growth. As well as, the present investigation showed that the adverse effects of water deficit on seed yield and yield components were significantly reversed by the exogenous application of glycine btaine (Table 1 and Fig. 1.A) Hussain et al., [16] found that exogenous glycine betaine application significantly improved various parameters of reproductive growth under water stress.

The seed yield was significantly influenced with the application of compost under different irrigation levels and significantly improved all the seed yield traits In comparison with control (Table 2 and Fig. 1.B). Consequently, combining deficit irrigation and organic matter can be the key to improve soybean yield under water scarcity, because organic matter improves soil water-holding capacity and increases water and nutrients availability for plant [17]. 
TABLE I: Effects of proline, Glycine betaine and compost application on seed yield and quality in soybean under water stress

\begin{tabular}{|c|c|c|c|c|c|c|}
\hline Treatments & $\begin{array}{l}\text { Number branch } \\
\text { per plant }\end{array}$ & $\begin{array}{l}\text { Number pods } \\
\text { per pod }\end{array}$ & $\begin{array}{l}100 \text {-seed } \\
\text { weigh }\end{array}$ & $\begin{array}{l}\text { Seed yield per } \\
\text { plant }(\mathrm{g})\end{array}$ & Protein $\%$ & Oil \% \\
\hline \multicolumn{7}{|c|}{ Soil Mois ture Level(A) } \\
\hline Control $(100 \%)$ & $4.12 \mathrm{a}$ & $40.24 \mathrm{a}$ & $10.93 \mathrm{a}$ & $16.47 \mathrm{a}$ & $39.9 \mathrm{a}$ & $16.4 \mathrm{a}$ \\
\hline $75 \%$ Of. Control & $3.64 \mathrm{~b}$ & $32.35 \mathrm{~b}$ & $9.44 \mathrm{~b}$ & $12.01 \mathrm{~b}$ & $31.4 \mathrm{~b}$ & $13.2 \mathrm{~b}$ \\
\hline $50 \%$ Of Control & $3.06 \mathrm{c}$ & $29.96 \mathrm{c}$ & $8.42 \mathrm{c}$ & $9.97 \mathrm{c}$ & $29.7 \mathrm{c}$ & $10.8 \mathrm{c}$ \\
\hline F. test & $* *$ & $* *$ & $* *$ & $* *$ & $* *$ & $* *$ \\
\hline \multicolumn{7}{|l|}{ Compost application (B) } \\
\hline control & $3.44 \mathrm{~b}$ & $32.65 \mathrm{~b}$ & $9.35 \mathrm{~b}$ & $12.37 \mathrm{~b}$ & $35.4 \mathrm{a}$ & $12.2 \mathrm{~b}$ \\
\hline compost (24 tha- $\left.-^{2}\right)$ & $3.78 \mathrm{a}$ & $35.65 \mathrm{a}$ & $9.84 \mathrm{a}$ & $13.26 \mathrm{a}$ & $32.1 \mathrm{~b}$ & $14.1 \mathrm{a}$ \\
\hline F. test & N. S & $* *$ & $* *$ & $* *$ & $* *$ & $* *$ \\
\hline \multicolumn{7}{|c|}{ Os moprotectants treatment $(\mathrm{C})$} \\
\hline Control (water) & $3.26 \mathrm{c}$ & $33.64 \mathrm{~b}$ & $9.27 \mathrm{c}$ & $11.75 \mathrm{c}$ & $31.5 \mathrm{c}$ & $11.5 \mathrm{c}$ \\
\hline proline $(25 \mathrm{Mm})$ & $3.90 \mathrm{a}$ & $34.98 \mathrm{a}$ & $9.97 \mathrm{a}$ & $13.88 \mathrm{a}$ & 35.7 a & $14.7 \mathrm{a}$ \\
\hline Glycune betaine $(25 \mathrm{Mm})$ & $3.65 \mathrm{~b}$ & $33.94 \mathrm{~b}$ & $9.55 \mathrm{~b}$ & $12.82 \mathrm{~b}$ & $33.5 \mathrm{~b}$ & $13.5 \mathrm{~b}$ \\
\hline F. test & $* *$ & $* *$ & $* *$ & $* *$ & $* *$ & $* *$ \\
\hline \multicolumn{7}{|l|}{ Interaction } \\
\hline$A \times B$ & ns & ns & ns & $* *$ & ns & ns \\
\hline A xC & $* *$ & ns & ns & $*$ & ns & ns \\
\hline $\mathrm{B} \times \mathrm{C}$ & ns & $*$ & ns & $*$ & ns & ns \\
\hline $\mathrm{A} \times \mathrm{B} \times \mathrm{C}$ & ns & ns & ns & $*$ & $* *$ & $* *$ \\
\hline
\end{tabular}

$*$ and **: significant at the $5 \%$ and $1 \%$, respectively. Means within the same column of each factor followed by a common latter is not significantly different at $5 \%$ level, by DMRT
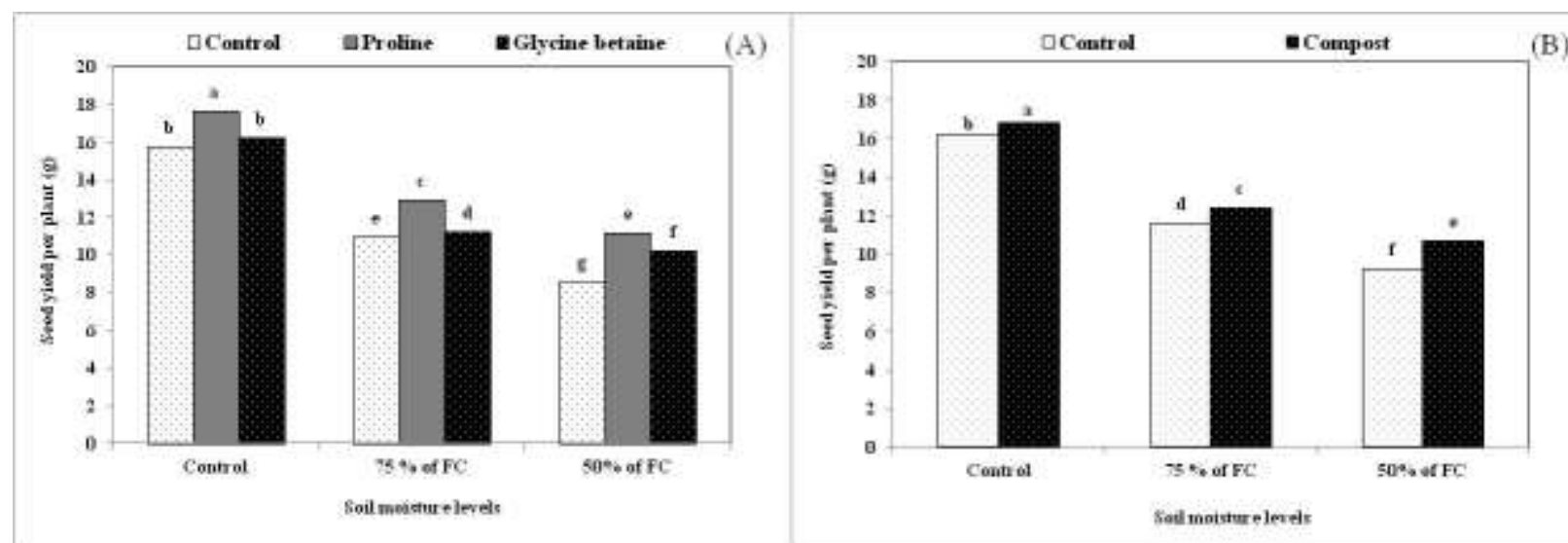

Fig. 1: Seed yield per plant in soybean as influenced by the interaction between proline, glycine betine and water stress.(A), and Seed yield per plant in soybean as influenced by the interaction between compost application and water stress.(B).

Means followed by the same letters in each trait are not significantly different at 5\% level, according to Duncan's test

\subsection{Seed quality}

According to the result under normal irrigation condition the maximum oil contents was recorded. While, the effect of water deficit treatments on oil content significantly reduced (Table 1). Water stress occurrence during critical periods of seed formation and seed filling stages reduces the content of seed oil. The reduction in the oil content under drought stress could be due to oxidation of some of the polyunsaturated fatty acids [18]. Similarly, the results of this study showed that the effects of water deficit treatments had significant reduced on seed protein content (Table 1). It seems that the decrease was due to a severe decrease in photosynthesis. Photosynthesis is decreased in drought stress and materials for protein synthesis are not provided; therefore, 
protein synthesis is dramatically reduced or even stopped [19]. On contrary, oil and protein content were significantly affected by exogenous of proline (Table 1). This ameliorating effect of exogenously applied proline on altering these seed chemical parameters might have been due to its role to maintain turgor in plants both under non-stress and water deficit conditions, there by maintaining high photosynthetic efficiency [20].The proposed functions of accumulated proline are osmoregulation, maintenance of membrane and protein stability [21].As well as, application of glycine betaine was effective on seed oil and protein content under water stress [22] (Table 1). In which it was reported that exogenous of a potential organic osmolyte glycine betaine showed ameliorating effects on these seed oil physico-chemical attributes under water deficit and non-stressed conditions. Taiz and Zeiger, [23] reported that improved the seed quality due to their protective effect on cellular structures during fatty oil biosynthesis and storage, which occurs in liposomes or oleosomes in seeds during seed filling stage.

In this concern, application of compost was more effective on seed protein content and may help to reduce adverse effects of water stress in oil content of soybean (Table 1). These results may be due to the effect of organic manure by improving the physical structure of the soil and increasing available nitrogen, which reflects the greater growth and, consequently, more absorption of nitrogen and more crude protein synthesis. Our results are in agreement with the findings of El-Sadek [24].

\section{Conclusion}

In conclusion, our study demonstrates that an exogenous of osmoprotectants and compost application in soybean crop could play an alternative way to improve the productivity when cultivated under water stress and ameliorated the negative effects of water stress on seed yield and quality traits. Consequently, it is evident that, the research will effectively solve seasonal water stress problem and can provide technical assistance for sustainable agriculture development.

\section{Acknowledgements}

Sincere thanks to all staff in Plant Nutritional Physiology Laboratory, Hiroshima University, Japan.

\section{References}

[1] N. Sionit, B.R. Strain, E.P. Flint, "Interaction of temperature and $\mathrm{CO}_{2}$ enrichment on soybean: Photosynthesis and seed yield,” Canadian Journal of Plant Science, vol. 67, pp. 629-636, 1987.

http://dx.doi.org/10.4141/cjps87-089

[2] M.S Pathan ,J.D. Lee, J.G. Shannon, H.T. Nguyen, "Recent advances in breeding for drought and salt stress tolerance in soybean. M.A. Jenks, P.M. Hasegawa, and S.M. Jain (eds). In: Advances in molecular breeding toward drought and salt tolerant crops," Springer Nether-lands. pp. 739-773, 2007.

http://dx.doi.org/10.1007/978-1-4020-5578-2_30

[3] E.A.Bray,J. Bailey-Serres, E. Weretilnyk, Responses to abiotic stresses. In W Gruissem, B Buchannan, R Jones, eds, Biochemistry and Molecular Biology of Plants. American Society of Plant Physiologists," Rockville, MD, pp. 11581249.

[4] G.Thapa, M. Dey, L. Sahoo, S. K. Panda, "An insight into the drought stress induced alterations in plants," Biol Plant, vol. 55, pp. 603-613, 2011.

http://dx.doi.org/10.1007/s10535-011-0158-8

[5] T. Hadiarto , L.S.P. Tran, "Progress studies of droughtresponsive genes in rice," Plant Cell Rep, vol. 30, pp. 297-310, 2011.

http://dx.doi.org/10.1007/s00299-010-0956-z

[6] M. Ibrahim, A. Hassan, M. Iqbal, E.E. Valeem, "Response of wheat growth and yield to various levels of compost and organic manure," Pakistan Journal of Botany, vol. 40, pp. 2135-2141, 2008.

[7] M. Tejada, M.T. Hernandez, C. Garcia, “ Soil restoration using composted plant residues: Effect on soil properties," Soil tillage research, vol. 102, 109-117, 2009.

http://dx.doi.org/10.1016/j.still.2008.08.004 
[8] AOAC, "Association of official agriculture chemists "official methods of analysis," $13^{\text {th }}$ Ed., Washington, DC, USA. 1980.

[9] R.G. Robinson, "Amino acids and elemental composition of sunflower and pumpkin seeds," Agronomy journal, vol. 67, no. 4, pp. 541-544, 1975.

http://dx.doi.org/10.2134/agronj1975.00021962006700040022x

[10] K. A. Gomez, A. A. Gomez, "Statistical procedures for Agricultural Research," $2^{\text {nd }}$ Ed. Johwiley and sons, Inc. New York. 1984.

[11] B. D. Duncan, "Multiple range and multiple F. Test. Biometrics", vol. II, pp. 1- 42, 1955.

http://dx.doi.org/10.2307/3001478

[12] M.Shahbaz, Y. Masood, S. Parveen, M. Ashraf, "Is foliar applied glycinebetaine effective in mitigating the adverse effects of drought stress on wheat (Triticum aestivum L.)?," Journal of Applied Botany and Food Quality, vol. 84, pp. 192-199, 2011.

[13] C. Demirtas, S. Yazg, B.N. Candogan, M. Sincik ,H. Buyukcangaz, A.T. Göksoy, "Quality and yield response of soybean (Glycine max L. Merrill) to drought stress in sub-humid environment," African Journal of Biotechnology, vol. 9, pp. 6873-6881, 2010.

[14] M. Ashraf, M.R. Foolad, "Roles of glycine betaine and proline in improving plant abiotic stress resistance," Environmental and Experimental Botany, vol. 59, pp. 207-216, 2007.

http://dx.doi.org/10.1016/j.envexpbot.2005.12.006

[15] S.H. Raza, H.R. Athar, M. Ashraf, A. Hameed, " Glycinebetaine-induced modulation of antioxidant enzymes activities and ion accumulation in two wheat cultivars differing in salt tolerance". Environmental and Experimental Botany, vol. 60, pp. 368-376, 2007.

http://dx.doi.org/10.1016/j.envexpbot.2006.12.009

[16] Hussain M., Malik M.A., Farooq M., Ashraf M.Y., Cheema M.A. "Improving drought tolerance by exogenous application of glycinebetaine and salicylic acid in sunflower," J. Agron. Crop Sci., vol. 194, no. 3, pp. 193-199, 2008. http://dx.doi.org/10.1111/j.1439-037X.2008.00305.x

[17] J.G. Wesseling, C.R. Stoof, C.J. Ritsema, K. Oostindie, L.W. Dekker, "The Effect of Soil Texture and Organic Amendments on the Hydrological Behavior of CoarseTextured Soils," Soil Use and Management, vol. 25, pp. $274-$ $283,2009$.

http://dx.doi.org/10.1111/j.1475-2743.2009.00224.x

[18] S. Singh, S.Sinha, "Accumulation of metals and its effects in (Brassica juncea L. Czern. cv. Rohini) grown on various amendments of tannery waste," Ecotoxicology and Environmental Safety, Orlando, vol. 62, pp. 118- 127, 2005. http://dx.doi.org/10.1016/j.ecoenv.2004.12.026

[19] K. D. Smiciklas, R. E. Mullen, R. E. Carlson, A. D. Knapp, "Soybean seed quality response drought stress and pod position," Agronomy journal, vol. 84, pp. 166-170, 1992.

http://dx.doi.org/10.2134/agronj1992.00021962008400020008x

[20] A. J. Ali, A. Nasser, "Salinity and salt composition effects on seed germination and root length of four sugar beet cultivars," Biologia, Bratislava, vol. 62, no. 5, pp. 562-564, 2007.

[21] H.E. Wahba, H.M. Motawe, A.Y. Ibrahim, A.H. Mohamed, "The Influence of Amino Acids on Productivity of Urtica Pilulifera Plant," 3rd International Conference of Pharmaceutical and Drug Industries Division, National Research Council, Cairo. 2007.

[22] Q. Ali, M. Ashraf, "Exogenously applied glycine betaine enhances seed and seed oil quality of maize (Zea mays L.) Under water deficit conditions," Environmental and Experimental Botany, vol. 71, pp. 249-259, 2011.

http://dx.doi.org/10.1016/j.envexpbot.2010.12.009

[23] L. Taize, E.Zeiger,"Plant Physiology", 4th ed.; Sinauer Associates, Inc.:Sunderland, MA,USA. 2006.

[24] A.N. El-Sadek, "Effect of some agronomic practices on sunflower productivity in new valley," Msc.Thesis, Faculty of Agric. Ain Shams Univ., Egypt. 2005. 